\title{
The Social Vocation of the Law and Criteria of its Legitimacy
}

\author{
Dzhamal Z Mutagirov* \\ Department of Political Sciences, St. Petersburg State University, Russia
}

*Corresponding author: Dzhamal Z Mutagirov, Department of Political Sciences, Professor of International Political Process, St. Petersburg State University, Russia

Submission: 睯September 28, 2017; Published: 眥 November 14, 2017

\begin{abstract}
Society is a natural association of people to solve together vital for all issues that are not under force to them alone. To answer such problems in the interest of all, the society generates many institutions, each of which has to answer a specific set of tasks. State and statutory law are among such established by the society institutions for protection of the rights and freedoms of their members, streamlining the relations between them and ensuring their security. The degree of democracy processes of their formation, the institutions' adherence to the public traditions and the effectiveness of control of the society over their performance determine the types of states, their social systems, and volume of the human rights, freedoms, and well-being of the people. Law, being an expression of the will of one person or group of people or society as a whole, governs all these processes. The article examines different understandings of the law and its role in people's lives.
\end{abstract}

Keywords: Society; State; Law; Democracy; The will of the people; The laws of nature; The laws of nations; The rule of law; Lawlessness

\section{Introduction}

Law, statutes and their interpretation directly affect vital interests of many people and therefore, supposedly for protection the interests of certain groups in society and under the guise of 'laws' some individuals, groups of people, including criminal could impose on societies their own will. Since the individuals or groups of people chosen by the heads of the legislative and executive branches, as well as political parties become lawmakers and interpreters of these 'laws', their social positions, contacts, likes and dislikes, as well as morality influence on them $[1,2]$.

Indeed, what are law and right? How they form? Who and how expresses the will of the people? The correct answers to these and related questions are extremely important for any society, therefore always remain to be the most vital, and at the same time relevant, that made them most actively discussed by people [3-7]. Why? It is because from the legitimacy of the law and any legislative act, including international ones and their interpretation, destiny not only of individuals but also of entire peoples, societies, states and even humankind as a whole depends.

\section{Literature Review}

The languages almost all the world's peoples understand the law as the correct, proper, natural, fair (right, recht, just, justice, pravo, etc.). Law, regulation, rule are something, which connects people, communities, determine and regulate their lives, just as universal gravitation defines a lot in life of the planet. They are also some kind human and social behavior's regulators, norms and rules, according to which community function.
Since ancient times, it is considered that law teaches man to control his passions, curb his desire, to defend what belongs to him, as well as to keep his mind, eyes and hands away from what belongs to others [8]. It intends to provide Justice's government, for as A. Augustine wrote a society without justice turns into a big gang of rapists and robbers [9].

Law and right are rules of things people should observe in life, both individually and collectively. The German political scientist Johannes Altusius (1557-1638) called the law the guiding light of civil life, the scale of justice, the preserver of liberty, a bulwark of public peace and discipline, a refuge for the weak, a bridle for the powerful, and straightened of imperium. He considered it as "the public command of the people, as well as the promise and assurance by the people that they will perform what is permitted and avoid what is not permitted. The law is also the precept by which political life institutes and cultivates according to a prescribed manner in the realm". Following tradition, he compared a role of the law in society with "such a Navigator on a ship, vehicle driver or conductor of an orchestra" [10]. The purpose of the law is an orientation of people to good and holds him from evil. Therefore, law is a set of rules the entire society's conduct [7]. The Islamic thinker Averroes also believed that the law's purpose is to establish the truth and faithful action, as well as an achievement of equality between human beings $[11,12]$.

Modern understanding of law and rights, their foundations and the spirit had formed under influence of the Roman and English Schools of philosophy of law. The Roman school believed that the 
law of nature underlies the law of the peoples. As Cicero wrought, they must find the true source of obligations and jurisprudence not in officials' edicts, as many lawyers believe, but in elevated positions of philosophy. The nature of moral justice coincides with the true nature of man. "The moral force of law not only much older than legal institutions of States and peoples, but is simultaneous with God himself, who manages both the heavens and the Earth", he assumed. The jurist often put before the noun "law" the definition "correct". According to him, such a combination firmly fixes law in the minds of people and makes it a rule of their actions [8]. Therefore, human consciousness, like wisdom, becomes law for them.

Nature has given people the law and justice; Justice is the basis of law, Cicero said. Law and justice are general rules for all living creatures; they underlie the Commonwealth, because people turn into citizens only when all residents of the Commonwealth share rules and recognize the same power. Law and justice are not inventions of one person only and not something abstract, but "the eternal principle that governs the universe, wisely commanding to do what is right, and forbidding what is wrong... For it is the reason and mind of Wisdom, urging us to good, and deterring us from evil". Thus, Cicero summed up that law is the nature's institution. In his view, 'law of nature' and the 'law of morality' are identical concepts. Socrates was right, hating those who carried out the differences between them and, considering this distinction the basis or the main cause of all human ills, Cicero wrote, and one of the first he turned to the saying: "a man appeals to justice and goes to law" [8].

According to the ancient Roman jurist, originally laws were adopting for the safety of the people, protection of the cities, for peace and benefit of society as a whole. Preventing violations under penalty, law plays a protective role. At the same time, Cicero refuted a claim that in our time stuck in the formula: "law is law" and it should unconditionally observed. If then in the majority of nations, many pernicious and mischievous enactments are made, as far removed from the law of justice we have defined as the mutual engagements of robbers, are we bound to call them laws?" he asked and without hesitation answered in the negative. "For as we cannot call the recipes of ignorant empirics, who give poisons instead of medicines, the prescriptions of a physician, we cannot call that the true law of the people, whatever be its name, if it enjoins what is injurious, let the people receive it as they will. For law is the fair distinction between right and wrong, conformable to nature, the original and principal regulator of all things, by which the laws of men should be measured, whether they punish the guilty or protect the innocent [8].

The lawyers of the subsequent eras also considered the law of nature as human life's basis and guide. According to Hugo Grotius they are constant, even God himself cannot change them [3]. Law of people must not contradict them, though they are an expression of their will, which largely depends on the degree of understanding the objective laws of nature, including the nature of their homeland. Law theorists of the society centrist view of all human institutions proved primacy of the objective laws of nature and secondary of the laws of the peoples and states.
The founder the first in the world Chair of the laws of the nature and nations at the University of Heidelberg S. Pufendorf (1632 - 1694) held the distinction between force, power, ability of the person and his rights. The first means that there is a marked ability without clear designation as it acquired. The right clearly shows that a person possesses and enjoys the relevant authority justly [5]. He called the right and duty moral qualities so interconnected and interdependent, that everywhere where there is an obligation of one person, the right of another person immediately appears. Pufendorf argued that people by their first agreement have established a society (civil society), by the second agreement - Republic, which he, like Cicero, understood as a common purpose (commonweal) and common wealth (commonwealth) of the people. Only by the third agreement, they formed the state and passed it certain authorities to ensure peace and security of their society. That is, the interests of societies and citizens are the basis and the objectives for which states exist and the authorities must serve the society. Rejecting the idea of absolute rights of rulers, he championed the notion of human freedom in establishing of public order and promoted the 'happiness of civil society in democratic governance' [4]. He wrote that every person as a social creature has a dignity and natural right to equality and freedom, including freedom of conscience and rejected the thesis of Aristotle on nature of slavery.

Professor of moral philosophy at Glasgow University, G. Carmichael considered John Locke's treatises of government as comments to the works of Pufendorf $[4,5]$. Schumpeter also named Pufendorf Locke's predecessor [7,9]. Indeed, the position of these authors of the same age is the same or very close to each other on many issues. Pufendorf was several ahead; Locke developed his ideas or came to the same conclusions.

According to the jurist from Geneva, J. J. Burlamaqui, who had compiled Pufendorf and Locke's views without references to them, the law of nature guides the human aspiration to happiness. This is a vocation of the civil laws as well. The task of the state consists in to make a person happier, and a calling of the laws is forcing people to become them. Burlamaqui [7] identified the law of the nature with the right to human happiness.

Simultaneously with the society centrist concept review and assess all socio-economic and political processes, the state centrist concept, according to which the state with a strong centralized authority is the heart, soul and lord of a society, existed, ever dominating and interfering with the understanding of true nature of social relations. According to one of the classics of this trend, Thomas Hobbes, "civil law, is to every subject, those rules, which the commonwealth hath commanded him, by word, writing, or other sufficient sign of the will, to make use of, for the distinction of right, and wrong; that is to say, of what is contrary, and what is not contrary to the rule" [13]. In his view, civil law is an obligation, some kind of shackles, depriving people of the freedom, which natural law gives them. He argued that while transiting to a state order, they had passed the state all their rights and freedoms. Pufendorf criticized Hobbes saying that a man always acts for the benefit of himself and establishing the state, he passes it only a part of his rights, retaining with him all the fundamental ones, including the 
right to control the activities of the new institute. Kant maintained a similar opinion. Always under the reservation that the real owner continues to have the right of a claim against the seller, on the ground of his prior alienated possession [14].

Hobbes' compatriot, one of the 'fathers' of English law, William Blackstone also interpreted laws as rules of human activity and behavior, like precepts that order a man, having the mind and freedom of choice, to use these qualities to regulate his or her conduct. Law's vocation, he wrote, consists in establishing the 'right' and 'wrong', what a member of the society and the citizen of the state can do and cannot do [15]

\section{Discussion}

The relations between members of the society and between citizens of the state are regulated by different rules, defining of whom are the civil society's rules. In nine out of ten cases of his life, a man guides by norms of his civil society-by norms of morality and social behavior developed by it for generations, cutting some of them and improving the others. There are some areas, the states must not entry in; their respective fields of competence are only civil-legal relations, concerning the human rights and security of the citizens. They have to protect those basic human rights that no way could abolish or limited by law.

Each law must be clear, crisp, concise and unambiguous. In ancient Athens, all citizens had the right to submit own draft of a law to the Assembly. The Special Committee of magistrates, whose task was protection of the laws, studied this draft, determined whether the proposed project contains ideas available in earlier legislation, and proposed to the Assembly to adopt the draft only if it contained something principally new. The author of the bill carried responsibility for it and afterwards. Any member of the Assembly could assert against it an accusation that the proposed and passed law contain some disadvantages. In case of confirmation of charges against the author of the bill, the last could be subject to strictly punishment, until to death.

Observing the law making activity of some modern 'legislators', especially in the State Duma of the Russian Federation, consisting mainly of representatives of the show business and executive powers' appointees [16], it would be nice if such a rule had continued to act and nowadays. Because of their 'omniscience and high legal competence', each year they try to set 'new records' for the number of hastily adopted, but far from reality, 'laws', absolute majority of which remain not understood by the society. They often do it without proper discussion, because one of the speakers of the legislature was of the view that 'parliament is not a place for discussions'. These 'experts' do not know that the more intense and accelerated a lawmaking process is, the short-lived the laws become [2], as well as the more laws establish what citizens can do and what cannot, the more low offences occur. Lawlessness in modern Russia clearly testifies to this. If remember the Hobbes assessment of statutes as shackles for people, more 'shackles' signify less freedom in the society and state.
Any law must meet certain obligatory requirements. Firstly, it should be desirable and feasible. Secondly, be useful and necessary. Thirdly, equitable and easy to order the nature of things are in the same way as the human physique [17]. Besides, the law must be the same for all members of a society, known to them and involve certain sanctions for deviation [10]. The commonality of the law, being an expression of the people's will, is the essence of democracy. The point does not change if special body enacts laws. This body is not over the people, but is an institute of the same people, consisting of its representatives, elected for a definite period with specific authorities. The people in a democracy are the supreme sovereign, over which there can be no higher power. Hence one of the most important maxims of democracy: "The will of the people is the highest law'. Any acts expressing the will and interests of some individuals or small group of society cannot and should not be legal and democratic. The very existence of such norms, paraphrasing Aristotle's words, witnesses about internal strife in a society. States where the law has no effect and is under the power of any group, are not strong. Only those, where law is Lord over the rulers and the rulers are the guardians of the law and his servants are durable [1].

The formula "ignorance of the law is no excuse" relates only to the law of nature. As to civil law, it can be true only if the law is an expression of the true will of the people's absolute majority, elucidation of which is done with maximum coverage of the citizens. The same act of elucidation becomes simultaneously a process of learning and memorization of the rules. Such a law grows into a rule of common law, which people observe automatically. The reasonable person cannot deviate from the rule of nature by virtue of its vitality. The same could be not extended to the cases when the usurper, tyrant, dictator or authoritarian politician try to turn their own will to law and impose it on society, not even trying to explain, where this solution stems from and why it received the status of law. It is clear that no reprisals are able to compel people to follow such a 'law', because reasonable people do everything on their inner promptings.

Law's affectivity always depends on its reputation and support of the people. Identity of the laws with the customs and traditions does this task easier, turns laws to a valid guide in life by weight and authority of their traditions. It is no coincidence therefore that the Italian philosopher and lawyer Bruno Leoni, summarizing nearly all the known interpretations of law, offered to understand it as a following of the members of societies and citizens of states the standards, which will allow them to reach the outlined goals [18]. In this case pursuit of own goals would be tantamount to life according to the law.

Each association of people produces, depending from geographical conditions, historical, national and other traditions of the country, its own norms and rules. Usually it takes decades and centuries. Even if the legislator is one person or a group of people, they should outcome from this reality. The more correctly this is done - the norm will be more effective and long lasting. 
Certain ratio between laws of the primary and secondary associations should remain in case of formation any confederations and federations. The norms of the primary associations as nearest the people keep priority. Much will depend on what the founders of the federation and the confederation agreed about, and what authorities they endowed the new entities, as well as on a degree of jealousy, with which they will monitor the unions' activity.

Only the will of the majority of the members of the society and citizens is a true law. Installation of this will with precision is a quite complicated task, and its elucidation ought to make with the greatest care and without haste. Legal acts adopted by a part of parliamentarians under the influence of momentary passions and sentiments, particularly in terms of "to ban", "to oblige", "to increase the responsibility' are of little use. Moreover, such 'shackles' are incompatible with increasingly expanding freedom of the citizens, being one of the fundamental human rights, in the name of ensuring of which the states exist. The law is a rule of human actions in the best for him and the entire society mode. Therefore, it must come from the system of national values, historical, geographical and other factors.

Shrewd T. Jefferson believed that at least one-year term must be since submission of the proposal to its adoption, and for amendments to the basic law - not less than five years. This is necessary to ensure multiple consults with civil society, with its different sectors, to identify their true will, and to consider their interests. Only the will of the nation makes laws required. One of the reasons for the laws of nature and time requirements, respectively, and their ineffectiveness, Jefferson believed, is the haste with which they were taken [19].

In some countries when adopting laws, particularly constitutional, they seek to take into account the will of different generations of the citizens as well. Therefore, the Greek Constitution provides that such laws be accepted by binding agreement of two convocations of the Parliament.

Parliaments of some countries demonstrate here inappropriate levity and irresponsibility. 'Lawmakers' here can sometimes solve the most important for society problems in some seconds. So, when discussing the agreement on the USSR' cessation of, signed in December 1991 by heads only three of the 15 republics, one of the deputies of the Supreme Council rightly observed that the treaty is signed by the President of a non-existent state, the Russian Federation, while its the true name was the Russian Soviet Federative Socialistic Republic (RSFSR). In response, the chairperson, to the same a doctor of sciences, found nothing other than to offer: "By the way, let's change the name of the State. Who stands for rename the RSFSR in the Russian Federation?" The hands of those with mandates of the deputies of the Supreme Soviet of the RSFSR obediently climbed up, thus depriving themselves, elected as deputies of the RSFSR, any legitimacy. Approximately the same had repeated when the third Russian President proposed to extend his mandate from four to six years and the so-called legislature in the pose of 'what next?' immediately without any debates legalized it.
The opinions neither the citizens nor the constituents of the Federal Republic had not been asked.

Another, in contrary, good example, shows the degree of democratic procedures for adoption of the constitutional laws and responsibilities of legislators. After the tragic events of September 11, 2001, the United States decided to create a Department of National Security. Debates on the law's draft in the Congress continued almost until the end of 2002, and the Law entered into force at the beginning of 2003, in accordance with presidential directive appeared on that Department in February 28, 2003. Three years later, a similar tragedy happened in the Ossetia city Beslan. A week after the tragedy (September 11, 2004) President of the Russian Federation voiced the idea of replacing the constitutional rule on governors' elections by appointments. The State Duma gave this idea the status of a constitutional law in October of the same year. In November, the Federation Council approved it, and December 6, 2004, the President signed his own decision, and it came into force. Thus, in one case since the introduction of draft amendments to the constitutional law prior to its approval and entry into force took more than a year and a half, while in the second case-only 73 days. Both of these options may be subject of emulation by other states, and the choice will depend on the degree of their democracy.

\section{Conclusion}

Democracy is a state of social relations characterized by rationality, freedom and equality of all participants, favors life and creative activity, as well as the persuasions of all members of the community of happiness. In the political sphere, this is the power formed by the people, for all its actions responsible before the people and serves the people [20] or, as the founding fathers of American democracy considered, "government of the people, for the people and by the people". The main vocation of the law and statutes consists in that their rules and regulations supported and constantly improved the democratic order. In reality, many frequently changing and contradictory laws and amendments do not adhere to the rules and principles of democracy. Moreover, there are many both conscious and casual deviations from laws. Everyone has to teach law and strongly keep its norms. It is said, when one student asked the President of the College after Washington, Robert E. Lee, what are the rules of the college, Lee answered: "there is only one rule: be a gentleman [21-23].

Paraphrasing Lee's words with relation to the laws of the societies and states, we can say that there is also only one rule: be worthy and responsible members both national and universal societies and responsible citizens of a democratic state.

\section{References}

1. (1983) Аристотель. Политика. Сочинения. Т. 4. М.

2. (2001) Wisdom of millennia's. Encyclopedia. Moscow, Russia.

3. Grotius H (1998) On the law of war and peace. Athens, Greece.

4. Pufendorf S (2004) Of the law of nature and nations. In eight books. Liberty Fund, Book VIII. 
5. Pufendorf S (2002) Of the nature and qualification of religion in reference to civil society. Translated by Jodocus Crull. Indianapolis, Indiana.

6. Vattel E (2011) The law of nations, or, principles of the law of nature, applied to the conduct and affairs of nations and sovereigns. Liberty Fund, Indianapolis, Indiana.

7. Burlamaqui JJ (2010) The principles of natural and politic law [1747]. Liberty Fund.

8. (2017) The political works of marcus tullius cicero: comprising his treatise on the commonwealth; and his treatise on the laws. Translated from the original, with dissertations and notes in two volumes. In: Francis Barham (Ed.), Esq. London, pp. 1841-1842.

9. (2017) A select library of the nicene and post-nicene fathers of the christian church, St. Augustine's city of god and christian doctrine. London-New York, 2: 1890.

10. Althusius JP (2004) Liberty Fund (1614), Indianapolis, Indiana.

11. (1921) The philosophy and theology of averroes. Baroda, India.

12. Supplements and observations upon the two books of Samuel pufendorf's on the duty of man and citizen according to the law of nature composed for the use of students in the universities. In: Gershom Carmichael (Ed.), Professor of philosophy in the university of glasgow (1724). Edinburgh, UK.
13. Hobbes Thomas (2011) The english works (1651). Liberty Fund, Indianapolis, Indiana, vol. 3.

14. Kant I (2013) The philosophy of law: An exposition of the fundamental principles of jurisprudence as the science of right (1796), p. 110.

15. Blackstone W (2010) Commentaries on the laws of england in four books (1753). Indianapolis, Indiana, 1: 49.

16. Mutagirov DZ (2015) Light and Shadow of political parties, or parties as actors and constraints of democracy. Political expertize politex 11(1): 25-37.

17. John L (2009) The two treatises of government $(1689,1764)$. Liberty Fund, Indianapolis, Indiana.

18. Hayek FA (1955) The political ideal of the rule of law. Cairo.

19. https://www.loc.gov/collections/thomas-jefferson-papers/about-thiscollection/

20. Sen A (2014) Democracy as universal value. Moscow, 'Logos', USA.

21. Liggio Leonard P (1980) Literature of liberty, Spring 3(1).

22. Mackintosh J, Vindiciae G (2009) Writings on the French Revolution (1791). Liberty Fund, Indianapolis, Indiana.

23. (1998) Democracy, Social Values, and Public Policy. Westport, Connecticut. London. 